\title{
No Future but a Shared Future
}

\author{
Lawrence O. Gostin \\ Georgetown University - Law Center - O'Neill Institute for National and Global Health Law, \\ gostin@law.georgetown.edu \\ Kevin A. Klock \\ Foundation for the National Institutes of Health, kklock@fnih.org \\ Sam F. Halabi \\ O'Neill Institute for National and Global Health Law, Georgetown University, sfh@georgetown.edu \\ Katie Gottschalk \\ O'Neill Institute for National and Global Health Law, Georgetown University Law Center, \\ kcg35@georgetown.edu \\ Katherine Ginsbach \\ O'Neill Institute for National and Global Health Law, Georgetown University Law Center, \\ kg802@georgetown.edu
}

This paper can be downloaded free of charge from:

https://scholarship.law.georgetown.edu/facpub/2420

https://ssrn.com/abstract=3977029

Think Global Health, November 28, 2021. This is a concise, edited excerpt from the report Legal Tools for Pandemic Preparedness: WHO Collaborating Center Support for New Coordinating Mechanisms, November 2021.

This open-access article is brought to you by the Georgetown Law Library. Posted with permission of the author. Follow this and additional works at: https://scholarship.law.georgetown.edu/facpub

Part of the Health Law and Policy Commons, and the International Humanitarian Law Commons 


\section{No Future but a Shared Future}

An Excerpt from Legal Tools for Pandemic Preparedness, the Report of the O'Neill/FNIH High-Level Meetings Supporting the WHO

Published in Think Global Health

November 28, 2021

https://www.thinkglobalhealth.org/article/no-future-shared-future

Lawrence O. Gostin, JD

O'Neill Institute for National and Global Health Law, Georgetown University Law Center

Kevin A. Klock, JD

Foundation for the National Institutes of Health

O'Neill Institute for National and Global Health Law, Georgetown University Law Center

Sam F. Halabi, JD, MPhil

Colorado School of Public Health, Colorado State University

O'Neill Institute for National and Global Health Law, Georgetown University Law Center

Katie Gottschalk, JD, LLM

O'Neill Institute for National and Global Health Law, Georgetown University Law Center

Katherine Ginsbach, JD, MS

O'Neill Institute for National and Global Health Law, Georgetown University Law Center

In September, the O'Neill Institute for National and Global Health Law and the Foundation for the National Institutes of Health (FNIH) convened 30 of the world's leading authorities on global health law, financing, biomedical science, implementation, and emergency response along with leaders from prominent international organizations deeply engaged in responding to the pandemic. This meeting was followed by regional consultations convened in Africa, Latin America-Caribbean, and Southeast Asia. The O'Neill Institute/FNIH also held a consultation with civil society representatives. What follows is a concise, edited excerpt from the full report, which may be downloaded at the following link: https://oneill.law.georgetown.edu/publications/legal-tools-for-pandemic-preparedness-whocollaborating-center-support-for-new-coordinating-mechanisms/

The COVID-19 pandemic revealed the fractured and inadequate state of national and global health law and institutions, revealing deeply embedded inequalities. The most important global health preparedness and response accord - the International Health Regulations (IHR)-does not provide incentives for investment in national capacities to prepare for, and respond to, infectious disease threats. The IHR also does not govern fair and equitable access to medical innovations and countermeasures. 
In an historic action earlier this year, 194 countries adopted a World Health Assembly (WHA) resolution ${ }^{1}$ to host a special session devoted solely to an international pandemic agreement, which will take place on November $29 .{ }^{2}$ The high-level experts who participated in our meetings after the resolution was adopted had in-depth discussions on the weaknesses and persisting gaps in global pandemic preparedness and what a new international agreement to address these voids might include. Generally speaking, they thought the special session should explore several vehicles, including political statements and resolutions, revision of the IHR, and an intergovernmental process to negotiate a new, legally binding international agreement, achieved through the exercise of the World Health Organization's (WHO) constitutional authority. ${ }^{3}$ None of these ideas preclude additional approaches, such as negotiating "soft" or non-binding instruments, forming or improving global public-private partnerships, or pursuing institutional modernization, including-and most importantly-strengthening of the WHO. These may be achieved along parallel tracks of negotiation and may ultimately be realized in combination.

\section{Recommendations and Political Statements}

Political statements have a useful signaling effect, but do not contain binding action requirements. Many of our experts believe that political statements in isolation are unlikely to initiate meaningful progress. One public health leader during our meetings demurred that he "gets paid to do, not to talk."

\section{A Revised IHR}

Article 21 of the WHO Constitution permits the WHA to "adopt regulations" concerning several enumerated matters; the IHR is based on such constitutional authority and its reform and revision is a viable possibility. It has already established broad areas of consensus for pandemic prevention and response, and calls for its reform signal a commitment to find a way to make it operate more effectively.

On the other hand, the IHR is a product of its time. It was designed to balance international travel and commerce with public health, and originally crafted prior to modern movements of people, capital, and goods. While respecting human rights, the IHR may still not adequately keep pace with a maturing international human rights regime. In fact, it could be argued that the IHR disincentivizes reporting, given the collateral consequences to national economies. At the same time, the timing and content of declaring Public Health Emergencies of International Concern have been highly controversial. ${ }^{4}$ Overall, closing these gaps in the IHR could improve pandemic preparedness, even if this addresses only part of the problem.

\section{A New Convention}

In theory, an international pandemic treaty could address global governance failures in comprehensive form. Under Article 19 of the WHO Constitution, the WHA "shall have authority to adopt conventions or agreements with respect to any matter within the competence of the Organization." So far, the WHO has utilized this treaty-making power only once, in the Framework Convention on Tobacco Control. An international instrument under Article 19 could initially establish broad areas for coordination and regulation and leave detail to later protocols and guidelines. In short, a framework convention-protocol strategy possesses a potential to achieve:

- an all-of-government and all-of-society approach that facilitates the coordination and participation of all relevant actors and stakeholders, including local communities; 
- a One Health approach that facilitates information sharing and coordination of activities between the human health, animal health, plant health, and environmental sectors;

- domestic legal preparedness for public health emergencies through a continuous process developing, reviewing, and updating laws, policies, and contingency plans;

- addressing many facets of risk management from risk mitigation measures to post-pandemic recovery; and

- adopting the risk communication and community engagement (RCCE) approach to the delivery of public health information, diagnostics, and treatments in the context of pandemics and epidemics.

This potential is necessarily limited by national sovereignty, prioritization of activities, and tailored responses fit to individual contexts.

A new international agreement will affect key aspects of human life governed by other treaties, including the UN Framework Convention on Climate Change, the UN Convention on the Law of the Sea, the Convention on Biological Diversity and its implementing Nagoya Protocol, human rights treaties, and others. There is a growing view that digital sequencing information (DSI) and genetic sequencing data (GSD), which are key to biodiversity management as well as pandemic preparedness, will be discussed in the next meeting of the Conference of the Parties to the Convention on Biological Diversity. In addition, a new international agreement could touch upon the mandates of other intergovernmental organizations from the WTO to UNICEF.

Several regional leaders who support an Article 19 agreement generally cautioned that effective regional strategies should not be usurped by a one-size-fits-all approach. Common diseases will be endured differently by different populations due to seasonality, health care capacity and other resources, and variations in communities' overall immune response to new pathogens.

Any instrument considered at the upcoming special session must have a dedicated team focused on areas of overlapping authority. The IHR and the Nagoya Protocol, for example, have specific provisions that contemplate additional or special international agreements, ${ }^{5}$ and those provisions must guide negotiations for a new pandemic instrument. What's more, an already stretched WHO should not be burdened with new tasks when other intergovernmental organizations are mandated, and better situated, to deliver on their comparative advantages. However, strong coordination between UN agencies and bodies is needed, and on global health, WHO should be in the lead. Importantly, any new international instrument must be harmonized with existing legal obligations, including those under the IHR.

\section{Drawbacks to Pursuing a New Convention}

Unsurprisingly, the major drawback to this mechanism is its barrier to entry. There is an inverse relationship between the rigor of substance and enforcement provisions and countries' willingness to accede without significant reservations, understandings, and declarations. WHA passage does not preclude domestic ratification procedures. Treaties take time to negotiate, leave supportive private and civil society sector partners at the periphery of discussions, and fall out of date. ${ }^{6}$

Also, a framework convention approach would require countries to reach consensus on short, definite timelines in order to negotiate later protocols, and to do so considering the priority likely to be given to national interests. Political and economic national priorities will be inclined to be put forward first, as has been the case during this pandemic. 


\section{We Are One Species}

The high-level listening sessions convened by the O'Neill Institute and FNIH identified critical gaps in global capacities for surveillance, data collection and sharing, communication, coordination, and response. These gaps overwhelmed governments and those tasked with response and health care at every level. No country was able to escape the virus.

This upcoming November 29 special session has been called historic-and certainly, the challenges it seeks to address are historic. To make groundbreaking progress will require imagination and courage so that the global right to health can be truly realized. As WHO Director-General Tedros remarked in his opening statement to our consultation:

The pandemic has taught us many lessons. The most important is that we are one species, sharing one planet, and we have no future but a shared future." 7

This article does not necessarily reflect the institutional views or positions of the O'Neill Institute or FNIH.

Reference List and Further Reading

${ }^{1}$ World Health Assembly, Special Session of the World Health Assembly to Consider Developing a WHO Convention, Agreement or Other International Instrument on Pandemic Preparedness and Response, WHA74(16), A74/VR/7, (May 31, 2021), available at https://apps.who.int/gb/ebwha/pdf_files/WHA74/A74(16)-en.pdf (last visited Nov. 26, 2021).

${ }^{2}$ WHO, WHASS2: Special Session of the World Health Assembly Referred to in Decision WHA74(16), https://www.who.int/news-room/events/detail/2021/11/29/default-calendar/second-special-session-of-theworld-health-assembly (last visited Nov. 26, 2021).

${ }^{3}$ Constitution of the World Health Organization, July 22, 1946, 14 U.N.T.S. 185, last amendment registered Sept. 15, 2005, 2335 U.N.T.S 18, available at https://www.who.int/governance/eb/who_constitution_en.pdf (last visited Nov. 26, 2021).

${ }^{4}$ See generally Lawrence O. Gostin, Global Health Law 189-92 (2014) (explaining the process for declaration of a Public Health Emergency of International Concern).

${ }^{5}$ International Health Regulations (2005) art. 14, May 23, 2005, 2509 U.N.T.S. 79, 252; Nagoya Protocol on Access to Genetic Resources and the Fair and Equitable Sharing of Benefits Arising from their Utilization to the Convention on Biological Diversity art. 4, Oct. 29, 2010, 3008 U.N.T.S 3.

${ }^{6}$ See generally Kevin A. Klock, The Soft Law Alternative to the WHO's Treaty Powers, 44 Geo. J. Int'I Law 821 (2013) available at SSRN: https://ssrn.com/abstract=3931956 (exploring the impediments to Article 19).

${ }^{7}$ Tedros Adhanom Ghebreyesus, Toward a Pandemic Treaty: Opening Remarks to Legal Tools for Pandemic Preparedness: WHO Collaborating Center Support for New Coordinating Mechanisms https://youtu.be/AYRQ9BD4OZM/ (last visited Nov. 26, 2021). 